PACS: 05.45.Xt, 74.50.+r, 85.25.Cp

UDC: 537.312 .62

\title{
Electrical properties of stacks of many long Josephson junctions
}

\author{
Alexandr Grib ${ }^{1}$, Ruslan Vovk¹, Sergii Savich¹, Volodimyr Shaternik ${ }^{2}$ \\ ${ }^{I}$ Department of Physics, V. N. Karazin Kharkiv National University, 4 Svobody Sq., Kharkiv 61022, Ukraine \\ ${ }^{2}$ G.V. Kurdyumov Institute for Metal Physics, N.A.S. of Ukraine, 36 Academician Vernadsky Boulevard, UA-03142 Kyiv, Ukraine
}

ORCID: 0000-0001-5772-9861

DOI:1026565/2222-56172018-29-02

We investigated numerically IV-characteristics and power of emission from stacks with various quantities of long Josephson junctions (up to 6 junctions) which interacted inductively with each other. Parameters of junctions were chosen close to those for MoRe-Si(W)-MoRe heterostructures. We set Gaussian spread of about $0.01 \%$ of critical currents along junctions. Electrical properties of a stack consisted of three junctions was investigated in details. Zero-field steps at voltages corresponding to frequencies of various modes of electromagnetic waves in the stack were found in the IV-characteristic. We showed that positions of zero-field steps in IV-curves were in good agreement with predictions of the theory. The highest maximum of power of emission corresponded to the so-called in-phase mode at which all voltages over junctions in the stack oscillate in-phase. Considering stacks with many junctions, we showed that power of emission at the voltage of the resonance which corresponds to the in-phase mode is proportional to the square of quantity of long junctions in the stack that is the characteristic of coherent emission.

Keywords: Josephson junctions; coherent emission; synchronization; zero-field steps.

$$
\text { О. Гриб, Р. Вовк, С. Савич, В. Шатернік }
$$

Ми дослідили чисельно вольт - амперні характеристики та потужність випромінювання пачок з різною кількістю контактів Джозефсона (до 6 контактів), що взаємодіють індуктивно один з одним. Параметри контактів були вибрані близькими до параметрів гетероструктур MoRe-Si(W)-MoRe. Ми задали гаусів розбіг критичних струмів близько $0.001 \%$ вздовж контактів. Електричні властивості пачки, яка складалася з трьох контактів, були детально досліджені. Сходинки нульового поля при напругах, які відповідали частотам різних мод електромагнітних хвиль в пачці були знайдені на вольт - амперній характеристиці. Ми показали, що положення сходинок нульового поля на вольт - амперних характеристиках добре узгоджені з теоретичними передбаченнями. Найбільший максимум емісії відповідав так званій синфазній моді, при якій всі напруги на контактах осцилюють синфазно. Розглянувши пачки з багатьма контактами, ми показали, що потужність емісії при резонансній напрузі, яка відповідає синфазній моді, пропорційна квадрату числа довгих контактів у пачці, що є характерним для когерентної емісії.

Ключові слова: контакти Джозефсона; когерентна емісія; синхронізація; сходинки нульового поля.

\section{О. Гриб, Р. Вовк, С. Савич, В. Шатерник}

Мы исследовали численными методами вольт - амперные характеристики и мощность эмиссии от пачек с различным количеством длинных джозефсоновских переходов (до 6 переходов), которые индуктивно взаимодействовали друг с другом. Мы задали гауссов разброс $0.01 \%$ критических токов вдоль переходов. Электрические свойства пачки, состоящей из трёх переходов, были подробно исследованы. Ступеньки нулевого поля при напряжениях, соответствующих частотам различных мод электромагнитных волн в пачке, были найдены на вольт - амперной характеристике. Мы показали, что позиции ступенек нулевого поля на вольт - амперных кривых находятся в хорошем согласии с предсказаниями теории. Наивысший максимум мощности эмиссии соответствовал так называемой синфазной моде, в которой все напряжения на контактах в пачке осциллируют синфазно. Рассматривая пачки со многими контактами, мы показали, что мощность эмиссии при резонансном напряжении, которое соответствует синфазной моде, пропорциональна квадрату количества длинных переходов в пачке, что является характерным для когерентной эмиссии.

Ключевые слова: джозефсоновские переходы; когерентная эмиссия; синхронизация; ступеньки нулевого поля.

\section{Introduction}

Recently, the huge progress was made in the creation of sources of coherent emission made of many intrinsic Josephson junctions on the base of high-temperature superconductors [1-3]. These sources work in the subterahertz and terahertz region of frequencies [1]. This

(c) Grib A., Vovk R., Savich S., Shaternik V., 2018 gives the possibility to develop ultrafast nonlinear terahertz spectrometers, terahertz imaging systems, the high-resolution Michelson interferometer [1-3]. It is proved experimentally and theoretically that the mechanism which leads to strong synchronization of radiation of junctions in the stack is connected with the interaction of Josephson generation with 
cavity resonances and the formation of self-resonant steps in the IV-characteristic in the absence of externally applied magnetic field (the so-called zero-field steps) $[4,5]$. In the present paper we apply basic ideas of the developed theory to stacks of junctions made on the base of low-temperature superconductors which can be more stable sources.

At first we discuss the formation of zero-field steps in the solitary Josephson junction. Zero-field steps are close related to Fiske steps which appear at voltages which correspond to frequencies of geometrical resonances in the system when the Josephson junction is placed in some magnetic field $[6,7]$. However, when the magnetic field is absent, steps in the IV-curve can not appear in the homogeneous junction [8]. If the distribution of critical currents is inhomogeneous and symmetrical (just this case we discuss in the paper), zero-field steps appear at voltages $V_{p}$ that correspond to even geometrical resonances:

$$
V_{p}=\frac{\Phi_{0} c p}{D}
$$

where $\Phi_{0}$ is the quantum of magnetic flux, $\mathrm{c}$ is the velocity of light in the junction, $D$ is the size of the junction and $p=1,2 \ldots$ is integer. It is proven also that some disorder of the distribution of critical currents leads to the formation of zero-field steps [9-11].

The theory of electric properties of stacks of Josephson junctions was developed and proved experimentally in Refs. [12-15]. One of the main results of this theory is that in the stack of $m$ junctions with inductive interaction between superconducting layers the Fiske step is split to $m$ branches. For example, the even Fiske step at the voltage $V_{p}$ calculated from Eq. (1) is split to $m$ branches which positions are determined as follows:

$$
V_{p, p^{\prime}}^{(m)}=\frac{\Phi_{0} c p}{D} \sqrt{\frac{1}{1+2 S \cos \left(\pi p^{\prime} /(m+1)\right)}},
$$

where $p^{\prime}=1 \ldots m$ is integer and $S$ is the normalized constant of inductive coupling of layers [13]. However, it has been shown that in the stack of two junctions with disorder of critical currents zero-field steps are split also [911], and positions of steps in the IV-curve can be calculated from Eq. (2). The coefficient $\alpha=L_{f} / L$ which characterizes the relation of the mutual inductance $L_{f}$ between junctions to the inductance $L$ of the junction in a stack [9-11] coincides with the constant of inductive coupling $S$ in Eq. (2). Due to the interaction between layers, some modes of excitations are formed in the stack and each of the branches of the zero-field step corresponds to its own mode. Amongst these modes there is the mode of fully coherent oscillations of all junctions (it is the so-called in-phase or coherent mode with $p^{\prime}=m$ which corresponds to the branch with highest voltage). Just at the branch of the coherent mode oscillations of voltages over junctions can be fully synchronized.
In the present paper we investigate numerically IVcharacteristics and power of coherent emission from stacks of long Josephson junctions. Parameters of junctions and the whole stack are chosen close to those for MoRe-Si(W)MoRe heterostructures which have appropriate values of the characteristic voltage and the density of critical current [16-18]. We discuss the IV-curve of the three-junction stack in details and prove the existence of the coherent mode. Then we investigate stacks with different numbers of long junctions and investigate the dependence of emitter power on the quantity of junctions at voltages of the in-phase mode.

\section{The model}

For calculations of IV-characteristics and power of emission from the stack of many long junctions we follow the method developed in Ref. [9]. Each of the long junctions with indices $i=1 \ldots m$ is divided to $\mathrm{n}$ segments with indices $j=1 \ldots n$. Each of the segments has the capacitance $C_{i, j}$ (we suppose $C_{i, j}=C$ for all segments) and the resistance $R_{i, j}$. Loops between centers of segments in each of the long junctions has the inductance $L$. Current conservation conditions and conditions of quantization of magnetic flux are as follows:

$$
\begin{gathered}
\frac{\Phi_{0} C}{2 \pi} \frac{d^{2} \varphi_{i, j}}{d t^{2}}+\frac{\Phi_{0}}{2 \pi R_{i, j}} \frac{d \varphi_{i, j}}{d t}+I_{c i, j} \sin \varphi_{i, j}= \\
=I_{b}-I_{i, j-1, j}^{R}+I_{i j, j+1}^{R}, \\
i=1 \ldots m, j=2 \ldots n-1,
\end{gathered}
$$

$$
\begin{gathered}
-L_{f} I_{i-1, j-1, j}^{R}+L I_{i, j-1, j}^{R}-L_{f} I_{i+1, j-1, j}^{R}+ \\
+\frac{\Phi_{0}}{2 \pi}\left(\varphi_{i, j-1}-\varphi_{i, j}\right)=0 \\
i=2 \ldots m-1, j=2 \ldots n,
\end{gathered}
$$

where $I_{b}$ is the bias current (we suppose that the same bias current flows through all segments, so the total bias current through the stack is equal to $\left.I=n I_{b}\right), \varphi_{i, j}$ is the difference of the phase of the order parameter across the segment, $I_{C i, j}$ is the critical current of the segment, $\Phi_{0}$ is the quantum of magnetic flux, $I_{i, j-1, j}^{R}$ is the ac current in the loop between two segments with indices $j-1$ and $j$ which are placed within the $i$-th long junction, $L_{f}$ is the mutual inductance between adjacent long junctions. To describe emission from the system, we attached contours with the resistance $R_{e}$, the inductance $L_{e}$ and the capacitance $C_{e}$ to the upper and lower superconducting electrodes at both ends of the stack. Then for junctions with indices $j=1$ and $j=n$ such equations are valid (boundary conditions): 


$$
\begin{gathered}
\frac{\Phi_{0} C}{2 \pi} \frac{d^{2} \varphi_{i, 1}}{d t^{2}}+\frac{\Phi_{0}}{2 \pi R_{i, 1}} \frac{d \varphi_{i, 1}}{d t}+I_{c i, 1} \sin \varphi_{i, 1}= \\
=I_{b}+I_{i, 1,2}^{R}-\frac{d q}{d t}, \\
i=1 \ldots m, \\
\frac{\Phi_{0} C}{2 \pi} \frac{d^{2} \varphi_{i, n}}{d t^{2}}+\frac{\Phi_{0}}{2 \pi R_{i, n}} \frac{d \varphi_{i, n}}{d t}+I_{c i, n} \sin \varphi_{i, n}= \\
=I_{b}-I_{i, n-1, n}^{R}+\frac{d q}{d t}, \\
i=1 \ldots m, \\
L_{e} \frac{d^{2} q}{d t^{2}}+R_{e} \frac{d q}{d t}+\frac{q}{C_{e}}=\frac{\Phi_{0}}{2 \pi} \sum_{i=1}^{m} \frac{d \varphi_{i, j}}{d t} \\
j=1, n,
\end{gathered}
$$

where $q$ is the charge that passes the inductance $L_{e}$. Normalized to the quantity of long junctions voltage over the stack is equal to

$$
V=\frac{\Phi_{0}}{2 \pi} \frac{1}{m n}\left\langle\sum_{j=1}^{n}\left(\sum_{i=1}^{m} \frac{d \varphi_{i, j}}{d t}\right)\right\rangle,
$$

where the sign $\langle\ldots\rangle$ means the averaging on time which is much large than the period of Josephson generation.

Ac power of emission $P_{j}$ from ends of the system was calculated as follows:

$$
\begin{gathered}
P_{j} \approx \frac{1}{R_{a}}\left\langle\left[\frac{\Phi_{0}}{2 \pi} \sum_{i=1}^{m}\left(\frac{d \varphi_{i, j}}{d t}-\left\langle\frac{d \varphi_{i, j}}{d t}\right\rangle\right)\right]^{2}\right\rangle, \\
j=1, n .
\end{gathered}
$$

The system of Eqs. (3)-(7) was solved by the method of Runge-Kutta. IV-characteristics and power of emission fro the left end of the stack $P_{1}$ were calculated with the use of Eqs. (8), (9).

\section{Results and Discussion}

Now we discuss main conditions for the formation of zero-field steps. One of them is the mentioned in the Section 1 inhomogeneous distribution of critical currents along the junction. In junctions made on the base of lowtemperature superconductors it is impossible to create the inhomogeneous distribution due to self-heating like it is in high-temperature superconductors [11]. The necessary distribution can be created by some disorder of critical currents. Another condition for the appearance of zero-field steps is that the frequency of the geometrical resonance should be inside the interval of frequencies of Josephson generation. To fulfill this condition, the stack should have a length of order of hundred micrometers. This means that junctions in such a stack have large capacitances. However, zero-field steps in IV-curves of junctions with large capacitances are hard to reveal. Both mentioned conditions are satisfied in heterostructures which consist of superconducting electrodes made of molybdenum-rhenium alloy with the critical temperature of about $9 \mathrm{~K}$ and a hybrid tunnel barrier made of silicon with nanoclusters of (the MoRe-Si(W)-MoRe heterostructure) [16-18]. These junctions have some capacitance due to non-fully grown nanoclusters. Our first treatment of IV-curves of such structures showed that zero-field steps appear in such structures [19].

At first, we calculated IV-characteristics and power of emission for the stack of three Josephson junctions with values of parameters close to those for MoRe-Si(W)-MoRe heterostructures. For the correct choice of parameters we introduced the fictive width of the stack $W=2.5 \cdot 10^{-4} \mathrm{~m}$. The length of the stack was $D=1.3 \cdot 10^{-4} \mathrm{~m}$. The density of critical current was $J_{c}=9 \cdot 10^{5} \mathrm{~A} / \mathrm{m}^{2}$, the critical voltage was $V_{c}=2 \mathrm{mV}$, the thickness of the superconducting layer was $\tau=60 \cdot 10^{-9} \mathrm{~m}$, the thickness of the barrier was $\delta=2 \cdot 10^{-9}$ $\mathrm{m}$, the velocity of light in the junction was $c=4.9 \cdot 10^{7} \mathrm{~m} / \mathrm{s}$, the capacitance per square area was $C_{d}=3.5 \cdot 10^{-3} \mathrm{~F} / \mathrm{m}^{2}$. Then we divided each junction in the stack to 60 segments with the length $\xi=D / n=2.17 \cdot 10^{-6} \mathrm{~m}$ and found for one segment $C=1.9 \cdot 10^{-12} \mathrm{~F}$ and the McCumber parameter $\beta_{C}=47.8$. The Josephson length of penetration of magnetic field was $\lambda_{J}=5.6 \cdot 10^{-5} \mathrm{~m}$, so the relation $\xi / \lambda_{J}<<1$ was fulfilled. The value of the inductance of the segment $L$ was defined from the relation $L=\xi^{2} /\left(c^{2} C\right)=1.01 \cdot 10^{-15} \mathrm{H}$. The value of the parameter $S=0.21$ was calculated with the use of Ref. [13]. We set Gaussian spread of critical currents $10^{-4} \bullet_{c}$ (or $0.01 \%$ ) for each of the segments. Parameters of external contours were $L_{e}=10^{-6} \mathrm{H}, R_{e}=300 \mathrm{Ohm}, C_{e}=9.6 \cdot 10^{-14} \mathrm{~F}$.

The calculated IV-characteristic of the three-junction stack is shown in Fig. 1a. In this plot we used reduced units, namely, $i=I_{b} / I_{c a}$ with $I_{c a}$ is the averaged critical current, $v=V / V c, p_{j}=P_{j} /\left(I_{c a} V\right)$. This IV-curve was obtained by means of sweeping of the bias current, i. e. the bias current in the hysteretic region was decreased to zero at the first sweep, then increased again above the hysteretic region, then was decreased to $i=0.34$ and then was increased again. According to Eq. (1), the zero-field step in the IV-characteristic of the solitary junction should be at $v_{p=1}=0.39$. For the stack with three junctions this zerofield step should split into three steps: $v_{p=1, p=1}=0.34, v_{p=1 \text {, }}$ $p^{\prime}=2=0.39$ and $v_{p=1, p^{\prime}=3}=0.47$. These modes are called as the anti-phase mode, the decoupled mode and the in-phase mode, correspondingly [20]. Calculated positions of steps are shown in Fig. 1a by arrows. It is seen that arrows almost coincide with steps. The plot of emitted power on the voltage is shown in Fig. 1b. As it was expected, the highest 

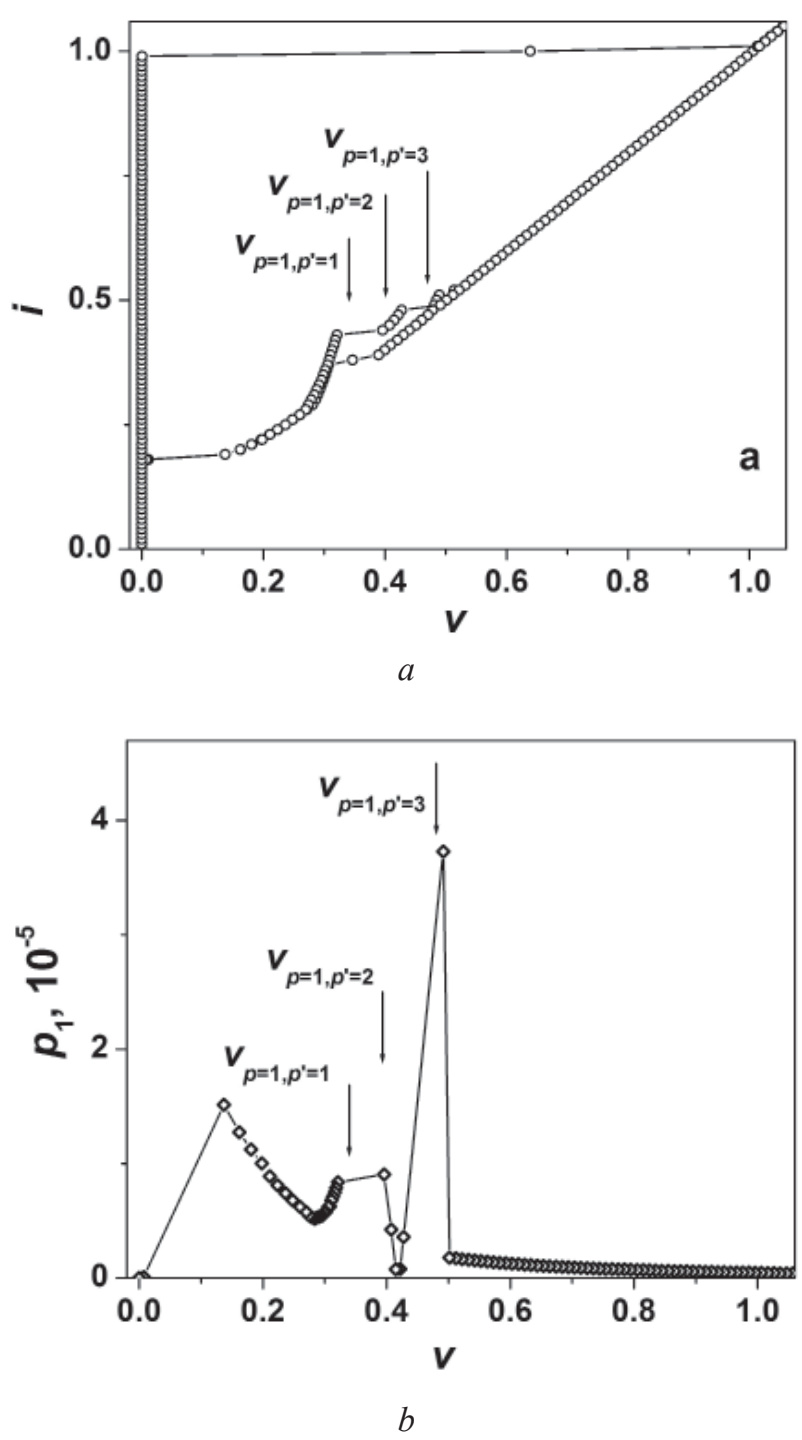

Fig. 1. 1(a): the IV-characteristic of the stack of three Josephson junctions. The curve is obtained during sweeping of the bias current. Positions of voltages of zerofield steps calculated with the use of Eq. (2) are marked by arrows. 1(b): the dependence of ac power on voltage.

maximum of $p 1(v)$ is at the voltage $v_{p=1, p^{\prime}=3}=0.47$, which corresponds to the frequency of the in-phase mode. Thus, we investigated electrical properties of the stack with three junctions with the small Gaussian distribution of critical currents and without applied magnetic field and found the good agreement of our numerical results for positions of zero-field steps and emitted radiation with predictions of the theory [12-15]. Note that earlier this theory was applied for Fiske steps of stacked junctions in magnetic field [13].

Now we investigate the dependence of power of emission in many-junction stacks on the quantity of junctions in the stack. We used such values of parameters: $\mathrm{W}=3.0 \cdot 10-4 \mathrm{~m}, \mathrm{D}=1.0 \cdot 10-4 \mathrm{~m}, \mathrm{Jc}=1 \cdot 105 \mathrm{~A} / \mathrm{m} 2$, $V_{c}=4.73 \mathrm{mV}, \tau=50 \cdot 10^{-9} \mathrm{~m}, \delta=2 \cdot 10^{-9} \mathrm{~m}, c=6.7 \cdot 10^{7} \mathrm{~m} / \mathrm{s}$, $C_{d}^{c}=3.5 \cdot 10^{-3} \mathrm{~F} / \mathrm{m}^{2}, n=60, \xi=1.67 \cdot 10^{-6} \mathrm{~m}, C=4.5 \cdot 10^{-14} \mathrm{~F}$, $\beta_{C}=62.0, \lambda_{J}=3.7 \cdot 10^{-5} \mathrm{~m}, L=1.36 \cdot 10^{-14} \mathrm{H}, S=0.21$, the

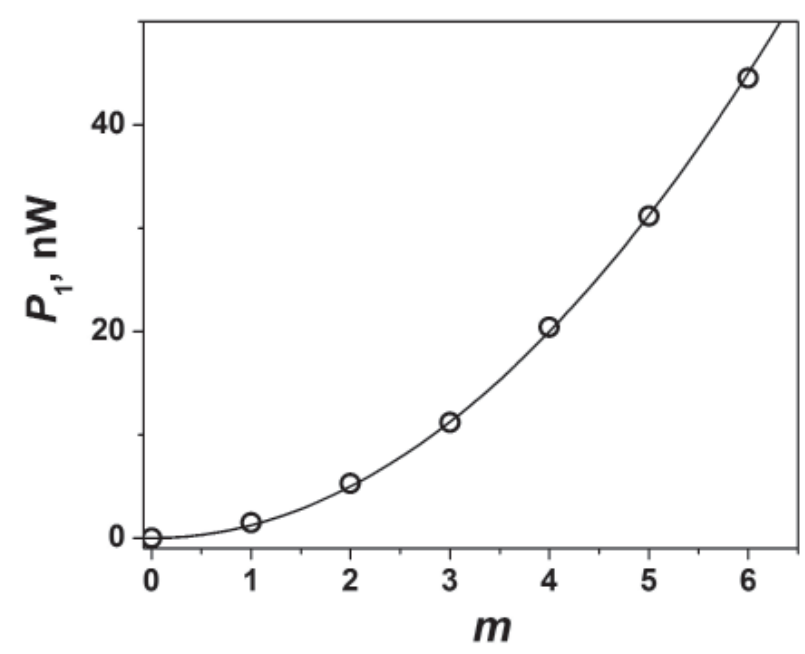

Fig. 2. The dependence of maximal power $P_{1 \max }$ emitted from the stack on the quantity of junctions $m$ in the stack. Solid line is the approximation of calculated data by the dependence $P_{l}(m)=A m^{2}$ with $A=1.25 \cdot 10-9 \mathrm{~W}$.

Gaussian spread of critical currents was $10^{-5} \cdot I_{c}$ and parameters of external contours were $L_{e}=10^{-6} \mathrm{H}, R_{e}=300 \mathrm{Ohm}$, $C_{e}=2.3 \cdot 10^{-5} \mathrm{~F}$. The first resonance step for the solitary junction calculated from Eq. (1) was equal to $V_{p=1}=0.29 \bullet V_{c}$.

In calculations we decrease the bias current in the hysteretic region and define power of emission from maxima of the plot $P_{1}=f(V)$ at voltages which correspond to in-phase modes. This method is usually used in experiments when the dc current-biased scheme is applied. The deficiency of this procedure is clearly seen from Fig. 1a. During the decrease of the bias current there is a jump of voltage from the resistive branch of the IV-curve to the step in the region of its bottom. The maximum of emission power is in the vicinity of the jump. The larger is the McCumber parameter the smaller is the jump, so it is hard to detect the solitary in-phase mode. Because the position of the right edge of the jump is defined by the step on the IV-curve, the obtained value of the power of emission at this point is the arbitrary point at the maximum. Therefore, we applied averaging of these values over 5-6 calculations of IV-curves with different steps.

The plot $P_{1}=f(m)$ is shown in Fig. 2 (circles). The solid line in this plot is the dependence $P_{l}(m)=A m^{2}$ with the coefficient $A=1.25 \cdot 10^{-9} \mathrm{~W}$ that is close to the value of emitted power for the solitary junction $\left(P_{1}(1)=1.5 \cdot 10^{-9}\right.$ $\mathrm{W})$. It is seen that the approximation describes our data with good accuracy. According to the theory of synchronization [21], in the case of fully coherent emission the ac emitted power is proportional to the square of the quantity of junctions: $P_{1}(m)=P_{1}(1) \bullet m^{2}$, where $P_{1}(1)$ is power of emission of one solitary long junction, and in the case of fully decoupled junctions the power of emission is equal to $P_{1}(m)=P_{1}(1) \cdot m$. Thus, we make a conclusion that at the in-phase mode voltage oscillations across long Josephson 
junctions in stacks are synchronized. With the use of this mode one can create sources of coherent emission.

\section{Conclusions}

In this paper we investigated IV-characteristics and emission of stacks with different amount of Josephson junctions which interact inductively with each other. We set small Gaussian spread of critical currents (about $10^{-4} \bullet I_{c}$ or $0.01 \%$ ) along junctions in stacks and found zero-field steps in IV-characteristics. We showed that voltages at which zero-field steps appeared can be calculated with the use of Eq. (2) of the theory [12-15] which was earlier applied to stacks placed in external magnetic field. This result is in agreement with our previous investigations [911] in which we found that the zero-field steps in a stack of two inductively interacting long Josephson junctions was split to two steps and positions of these steps in the IV-curve was defined by frequencies of normal modes. We also investigated the dependence of emitted power at the voltage which corresponds to the frequency of the in-phase mode and proved that voltages across long junctions in the stack oscillate in-phase.

\section{Acknowledgement}

This publication is based on the research provided by the grant support of the State Fund for Fundamental Research (project $\Phi 76 / 36725$ ).

\section{References}

1. Kurama Nakade et al., Scientific Reports, 6, 23178 (2016).

2. H. Minami et al., Phys. Rev. B, 89, 054503 (2014).

3. T. M. Benseman et al., Appl. Phys. Lett., 103, 022602 (2013).

4. L. Ozyuzer, et al., Science, 318, 1291 (2007).

5. A. E. Koshelev, L. N. Bulaevskii. Phys. Rev. B77, 014530 (2008).
6. I. O. Kulik. Zh. Eksp. Teor. Fiz. Pis. Red., 2, 134 (1965) [JETP Lett., 2, 84 (1965)].

7. Antonio Barone, Gianfranco Paternò. Physics and applications of the Josephson effect, John Wiley and sons, New York. (1982), 529 p.

8. C. Camerlingo, M. Russo, R. Vaglio, J. Appl. Phys., 53, 7609 (1982).

9. Alexander Grib and Paul Seidel, IEEE Trans. Appl. Supercond., 26, 1801004 (2016).

10. Alexander Grib and Paul Seidel, IEEE Trans. Appl. Supercond., 27, 1800604 (2017).

11. Alexander Grib, Paul Seidel and Masayoshi Tonouchi, Supercond. Sci. Technol., 30, 014004 (2017).

12. S. Sakai and P. Bodin, N. F. Pedersen, J. Appl. Phys., 73, 2411 (1993).

13. S. Sakai, A. V. Ustinov and H. Kohlstedt, A. Petraglia and N. F. Pedersen, Phys. Rev. B, 50, 12905 (1994).

14. R. Kleiner, P. Müller, H. Kohlstedt. N. F. Pedersen, S. Sakai, Phys. Rev.B, 50, 3942 (1994).

15. R. Kleiner, Phys. Rev.B, 50, 6919 (1994).

16. V. Shaternik, A. Shapovalov, O. Suvorov, N. Skoryk, and M. Belogolovskii, Low Temp. Phys., 42, 426 (2016)

17. V. E. Shaternik, A. P. Shapovalov, O. Yu. Suvorov, Low Temp. Phys. (Fiz. Nizk. Temp.), 43, 877 (2017).

18. V. E. Shaternik, A. P. Shapovalov, T. A. Prikhna, O. Y. Suvorov, M. A. Skorik, V. I. Bondarchuk, and V. E. Moshchil, IEEE Trans. Appl. Supercond., 27, 1800507 (2017).

19. A. Grib, S. Savich, R. Vovk, V. Shaternik, A. Shapovalov, P. Seidel, IEEE Trans. Appl. Supercond., in press.

20. C. Gorria, P. L. Christiansen, Yu. B. Gaididei, V. Muto, N. F. Pedersen, M. P. Soerensen, Phys. Rev. B, 66, 172503 (2002).

21. K. K. Likharev. Dynamics of Josephson junctions and circuits, Gordon and Breach, Philadelphia. (1991), 750 p. 